\title{
ABOLITION OF 'KIPAT' LAND TENURE SYSTEM: THE CONTEXT AND CONSEQUENCES
}

\section{Ram Kumar Ghimire *}

\begin{abstract}
'Kipat' was tenure of land existing mainly in Eastern part of Nepal. This was a communal land holding by the Kirats of the then Majh and Pallo Kirat area. After the unification of the modern Nepal, late king Prithivinarayan Shah also established the type of tenure in the same manner as it was in the control of the Kirat tiny state. The land tenure system of Kirat was communal. The land was not saleable to other persons who were not the progeny of the first user and maker of the Pakho-Banjo to arable land. It might be given as Dan; the Jimmawala might give it by Pajani. The land ultimately was the property of King, and King could make and change on the holding for social use.
\end{abstract}

Kirat area was not the conquered part of Nepal but it was annexed in Nepal by negotiation between the Kirata and the ruler of Nepal. Limbu, Rai and Khumbu devoted land to the king to win mercy and obtain the ranks like Subba, Majhiya, Jimi etc. Mahesh Chandra Regmi claims that Tamang, Sherpa, Kumhal and Lepcha had also this form of tenure. Similarly, Tamang of East No. 1 and 2 and Majhi-Bote of Palpa and Achham had tiny Kipat land. But Sherpas of eastern Nepal had no such tenural land. The Rana rulers had also continued the Kipat land tenure system. After the dawn of democracy, the overall pattern of governance changed. In this context, different segments of people raised issues of political and social change. The change of land tenure system was also one among them. The UN agency FAO started to lead for positive changes on land issues. In the 60s, like most of others LDCs, Nepal had adopted the state-led land reform program. In this context, the Land Reforms Act, 1964 was proclaimed. The Land Act was amended many times; Kipat was abolished by the $2^{\text {nd }}$ amendment of the Land Act.

The consequences of the Kipat abolition did not show greater influence in social setting, national polity and economy. Some minor effects were shown in this context. Kipatias were from ethnic group. Their main occupation was traditional but after the first and second War, they joined British army in a large number. Some of the Kirat started to go to the India for extra earning. When the income rose, they started to migrate to Tarai. Kipatias could sell their parental land as they need not tie up with the parental land. The abolition of this tenure did not create any kind of problem in social setting.

The political power was not centered on some handful persons due to the 'Kipat' system. 'Kipat' was not like the Jimindari system, and there was no masterservant relationship between peasants and Jimmawals. Generally, the decision was made in Kipatia society by social consensus, but not by any order of Jimmawal.

\footnotetext{
*Associate Professor, Central Department of Education, Tribhuvan University, Kirtipur, Nepal
} 
The land-holding pattern was not in big scale in 'Kipat' tenure, so there was less room for the distributional effect. The data were not proper so how much land was changed to Raikar after the abolition of 'Kipat' is some how unknown. The overall effect was not substantially shown due to the abolition of 'Kipat' tenure. So, it can be said that due to the abolition of 'Kipat' tenure administrative reform was made but not economic reform. After the abolition of 'Kipat', land was not distributed or consolidated. Holding pattern was not changed. 'Kipat' land was not so highly productive land. Mostly 'Kipat' was in hilly region and the quality of the land was not so good. By this, it can be projected that extra revenue from 'Kipat' abolition is not significant.

\section{INTRODUCTION}

Kipat was tenure of land existing mainly in eastern part of Nepal. This was a communal land holding by the Kirats of the then Majh and Pallo Kirat area. The unification expedition of the late king Prithvinarayan Shah established this type of tenure in modern Nepal in the same manner as this area was in the control of the Kirat tiny state.

The Kirats are the ethnic group residing in eastern Nepal. They claim that they are indigenous residents of Nepal. But the question whether peoples of other castes and races were or were not living within the territory where communal tenure existed is unanswered. The historians claim that Aryas are new comers to the Kirat areas, Majh Kirat and Pallo Kirat. The Magar and Gurungs also seem so because they were recruited during the unification campaign of Prithvinarayan Shah. But within this Kirat areas there are Sherpa in the high altitudes of mountains and hills. So the existence of other tenure with the Kirat area is more possible. Shyam Sundar Sherpa (2002) claims that Sherpas are indigenous people and Kirats are those ethnic groups in eastern hill who are living there before Aryas, Gurungs and Magars. Kirats were the Royal community in Kathmandu valley before Lichchhavi of Baisali, India won the throne in $2^{\text {nd }}$ century. By this loss of land and throne the peasant Kirats were shifted to eastern hill for their livelihood. Kirats weren't as modern in their technology in agriculture as Lichhavi and Aryas. The main occupation of Kirat of that time was hunting, farming and agriculture.

The historians had laid emphasis on researching the history of valley only. So the history of Kirats became somehow unclear, when they were shifted forcefully to eastern hills. Historians say there were two kingdoms in eastern hill, Majh Kirat and Pallo Kirat. The main area of Kirat is Koshi-River-Hill area. Presently, they are residing from Sunkoshi to Tamor valley slopes in Nepal. They are residing in Sikkim and Northeast India also. But their parental land is basically Koshi-River-Hill.

Rai, Limbu, Khumbu, Yakkha, Athpahariya, and Sunuwar are the ethnic communities of Kirats. The spiritual and social system of Kirats are basically derived from the 'Mundhums'; an unwritten policy guideline influenced by nature. Kirats are devotees of nature, local hills, rivers and other physically existing commodities like Sun, Fire etc. Tensi Sirijanga invented Kirat script and collected the Mundhum, which is regarded as the first written Mundhum. 
The land tenure system of Kirat was communal. The land was not saleable to other persons who were not the progeny of the first user and maker of the Pakho-Banjho land to arable land. It might be given as Dan, the Jimmawala might give it by Pajani- a type of order to rearrange or give to the follower and/or to the sycophants and their family relatives; but could not be sold. The land ultimately was the property of the king, and the king could make any change on the holding for social use. But generally, he didn't change the individual ownership for personal use.

The unification expedition of late King Prithvinarayn Shah created a threat to the ruler of Kirat from western side. The conquest of Bijayapur and Chaudandi by Greater Nepal made the Kirats aware of an immediate attack. In the eastern side King of Sikkim was a headache for Kirats of Koshi hills. King of Sikkim was Lepcha, and indigenous tribe. He also wanted to include Kirat area in Sikkim kingdom. The Kirat rulers feel greater threat from Gorkha-Nepal Kingdom. So they decided to accept to include Kirat area in Greater Nepal. They signed a treaty with the king of GorkhaNepal kingdom. However, social, spiritual and administrative setting did not change in Kirat area. The land tax had to be collected from the ex-ruler of Kirat area and it had to be paid to the king of Greater Nepal if and only if Nepal had greater financial problem. Otherwise, the land tax was the income of ex-ruler of the Kipatias. According to the treaty, security of Kirat area was to be made from Nepal kingdom and land tax was to be exempted for Kirats in Kipat land. By this warless peaceful unification the Kirats had the right to land in the same manner as it was before unification. This type of land granted to Kirats by the special Royal Order was known Kipat (Regmi 1977).

Regmi writes, "the assurance to let Kipat as it remains in existence did not satisfy the Limbus of Pallo-Kirat, the large numbers of them preferred migration to the adjoining areas of India and Sikkim to the protection offered by Prithvinarayan Shah in 1974 AD Kathmandu, then, confiscated the Kipat holding of the fugitive Limbus and granted that to non Limbu settlers under Raikar or Birta tenure. Again in 1895 and some other time the government proclaimed and requested to return the fugitive Limbus to return Nepal and the land was also returned them and all the crimes defined by the government have pardoned (Shrestha 1985).

There were Talukdar and Subba in 'Kipat' Limbuwan area. Subba had all rights of other types of Jimidars. In addition to that, he had a legal right to see the cases except Panchakhat. Appeal could be made in court and in Amini Tribunal. The tribunal of Subba was said Amalkao Kachahari. The legal right of Subba was confiscated in 2016 BS The eldest son had the right of Subba. A Subba could appoint some Tharis within the territory of their Subbngi. Subba had the right to collect the Beth, Begar, Chardam, Theki, Korali etc. This right was confiscated in 2007 BS. Subba collected Serma, a tax imposed on family, and Saune Phagu, a tax imposed on the number of houses. Some part of this tax was given to Thari too. A Subba could only give land by Pajani to the Kipatiya raiti. A son of Subba could get the rank Subba if he devoted 60 Muris land (soil) and Rs. 52.00 as Salimi to the King although he was not the eldest son of Subba. This land was registered as Raikar and registered in his own name. 
In Wallo and Pallo Kirat Limbus, Rais and Khumbus devoted land to the king to win mercy and to obtain the ranks like Subba. Majhiya, Jimi etc. There was no any record to show how much land was converted to Raikar and Birta from first type described by Regmi, how much land came to this tenure for new cultivation and how much land came to these tenure by devotion of Kipatiyas.

Mahesh Chandra Regmi claims that Tamang, Sherpa, Kumhal, and Lepcha had also this form of tenure. Similarly, Tamang of East No. 1 and 2 and Majhi-Bote of Palpa and Achham had tiny Kipati land. But Sherpas of eastern Nepal had no such tenural land when there was no any evidence to show that the Kipat tenure had been taken away from Sherpa. It might be the case that Sherpas were not royal families. So the land held by them was under the control of Kipatiyas. In the Kipat areas, when it was not abolished, there were small plots of Raikar lands within the boundaries of 'Kipat' and some small Kipat holding within Raikar tenure also. Many of the Kipatiyas devoted land to the King of Nepal to win his mercy for the rank of Subbha, Jimdar, Dasmajhiya, Rai, Jimi, etc. This system became continue for a long period. The Rana rulers had also continued the system. The last update was made in 2016 BS by late King Mahendra.

The democratic movement of 2007 BS changed the overall pattern of governance. Many attempts were made for the reform of the society and governance in Nepal. The end of World War-II and wave of democratic and socialistic movement made all nations aware of new settings. Nepal accepted Rightist movement and acted as that of India. In India and other UN member countries, land reform was introduced for social, economic and political transformation. The entry of Nepal in UN in 1955 AD and the technical and financial help of that organization compelled Nepalese Government for economic and social reform. In this context some attempts were made in land holding, tenure and administration.

In the chain of reform in land, landed property and peasant right, Kipat tenure was abolished by the second amendment of the Lands Act-2021 BS in 2025/7/9 by the Chapter 2 section 3 ka that reads as follows:

1. Kipat land can be registered as Raikar.

2. Land tax will be imposed on Kipat land as that of Raikar

\section{CONTEXT}

In the international sphere there was a rapid change after the World WarII in land holding, use of labour, and different development issues. After the establishment of the UN a separate institution was established under UN to see land and food problems. FAO was that institution, which started to lead for positive changes on land issues. It started to initiate, assist, implement, lead, make research, and thus, initiate a new era for land and peasant development.

The land reforms in the 50s, 60s, and even in the 70s were the influence of the communist ideology on liberal economy. To quote FAO officers "The Russian Revolution in 1917 and a variety of national socialist as well as populist regimes between the First and the Second World Wars moved the ideology of agrarian reform in the western world from a liberal economic process to a state 
engineered way of redistribute land and achieve equality in rural areas" (Herrerra, Riddell, Toselly 1977).

This pressure on the liberal and rightist sphere made the land reforms an inevitable necessity of all UN members. So FAO was the leader on the land issues. In the 60s, like most of other LDCs, Nepal adopted the state led land reform programs, combining some almost unique programs e.g. compulsory saving, credit amortization etc. The land reform program of Nepal came in a special and critical political period. The multiparty system was replaced by a nonparty Panchayat system. The power was at the hands of some handful landlords. The political influence of landed aristocrats was so high that almost all practices to implement the reform on land were made unsuccessful. The banned political parties were awarding the rural poor people against the exploitation which had to be borne by them from the landed aristocrats. The government wanted to make happy both the opposite aimed groups by a single law. In this context the Land Reforms Act, 1964 was proclaimed. The landed person had thought that this program would also be failure by their pressure. On the other hand the marginal people hoped that this law would bring equality in rural economy. But the hope of both groups was not fulfilled. The political power of landed person has shifted to the government and economic inequality remained as same as it was during preland reform period. So we can say that other objectives of land reforms political objective, administrative objective, objective of cross-cultural interaction etc. were achieved but the economic objective was not achieved in its entirety. The whim was shifted elsewhere in international circle, the hope of people decreased in the process of implementation, and other causes decreased the attraction of scholars in land reform issues. Two amendments were made within four years of declaration. The law came into force in 16 districts in 2021 BS, in 25 districts in 2022 BS and in remaining 34 districts in 2023 BS. The second amendment abolished the Kipat so there was not room for huge pressure against the abolition of the Kippat tenure.

In the decades of the 50s and the 60s Nepalese society was backward. The government of that time was trying to transfer the society at least in their proclamations. In this context Kipat abolition was the last straw that would break the camel's back, although its implementation was intentionally or unintentionally very slow. In 2020 BS, New Civil Code was announced and this act abolished caste system legally. Similarly Land Act 2021 BS abolished the landlordism i.e. Jimindari. At last Kipat was abolished in 2025 BS in the $2^{\text {nd }}$ amendment of the Land Act 2021 BS. This was the last abolition of tenure abolished by law. Presently non-abolished two tenures are existing, namely Rraikar and Guthi. Although, administratively, Bitauri, Ailani and some other types of land are still in existence, but, except Guthi all are treated as Raikar.

Declaration of previous governments also laid emphasis to abolish the Kipat tenure. In 2016 BS the then government has initiated to lobby for the abolition of Kipat. The parliament passed the bill to abolish Birta and Rajya Rajauta. In parliament a proposal was submitted by the then MP Prem Raj Andambe, a member of Kipatia tribe, to initiate the Kipat abolition. A wide discussion was made in this connection but the bill was not passed to abolish Kipat tenure. When Jamindari was 
abolished by the Land Act 2021 B.S., Jamindars also criticized the government for abolishing the Jamindari and not abolishing the Kipat tenure. The government then amended the act and abolished the Kipat tenure.

Political change occurs in a nation by the co-incidence of internal and external causes. In Nepal external causes seem more powerful than internal causes. But the public faith in the existing ruler does and strongly does matter. In this political change of 2007 BS. Kipatiyas did not support Rana ruler. Nepali Congress was able to collect vote from Kipat area in 2016 BS election. But the submission of proposal to abolish Kipat and passing of bill to abolish Birta and Rajya Rajauta tenure initiated by Nepali Congress angered power holding group of the society and they didn't protest the 2019 BS political change. King Mahendra was familiar to this matter. But it was his compulsion to abolish the remaining tenures. So he made a good arrangement to announce the Land Act. He declared the act but it was not imposed at once. He made some loopholes to make necessary arrangements for Jamindars. Similarly, Kipat abolition was announced after many years of the discussion. If something was done before the actual announcement was made, all could be done.

The background of the land reform was slow. Different measures were made to reform land and landed property after the planned development was initiated. Some of the Acts that were announced before Kipat was abolished by the $2^{\text {nd }}$ amendment of Land Act 2021 BS in 2025/07/09 BS are:

- $\quad$ Tenancy Right Acquisition Act, 1952 AD

- $\quad$ Land Reform commission, 1952 AD.

- $\quad$ Royal Announcement of 1955 AD

- $\quad$ Lands Act, 1957 AD

- $\quad$ Birta Abolition Act, 1955 AD

- Rajya Rajauta Abolition Act, 1955 AD

- $\quad$ Rkoyal Land Reform Commission, 1959 AD

- $\quad$ Land (Measurement) Act, 1962 AD

- $\quad$ Agricultural Reorganizations Act, 1963 AD

- $\quad$ Land Administration Act, 1966 AD

- $\quad$ Act to manage (Sale and Distribution) of the Land of Rapti Dun i.e. Valley Development Region, 1966 AD.

The series of change was the main cause of Kipat abolition. Its announcement was expected by its implementation was very slow. So the causes and consequences both are scattered and mixed with other, political and economic phenomena. It made more complicated to analyze the causes and consequences of the Kipat abolition.

\section{THE CONSEQUENCES}

The consequences of Kipat abolition did not show greater influence in social setting, national politics, and economy. Some minor effects were shown in this context.

\section{SOCIAL CONSEQUENCES}

The Kipatias were from ethnic group. Their main occupation was traditional. Kirats were recruited into the British and Indian Army due to the 
effect of World War-I and II. Their income rose due to this reason. This made Kirat a bit more mobile than other residual of eastern hill. Kirats, being physically strong, went to India and Muglan for extra earnings for decades. So, they were familiar to other communities also. Due to these and other reasons, Kirats were friendly to other ethnic and racial groups. The effect of Kipat abolition on society was not counter-effective to social harmony.

The abolition of Kipat made easy to transfer the ownership of land. So, migration was made easy to able persons. Kirats were migrated to Dharan, Damak and other Tarai regions after land reform was made. Migration was made easy by the abolition of Kipat as the Kipatias could sell the land with ownership and they did not have to tie up with the paternal land. It made them free to double housing in hills, the parental land where their ownership of land became transferable and Tarai where they were trying to establish new settlement. Not being a member of Kipatias, and being a member of new generation, the researcher does see the negative consequences of Kipat abolition.

Today, Kipat tenure is a history of Nepalese land tenure system. The system had existed due to the harmonic unification of the territory with Nepal. The abolition of this tenure did not create any problem in political, economic and social settings of modern Nepal. So, it is a glory of our history and a base of our socio-economic culture. It will be cited in history by golden letter that there was tenure existed with harmony and abolished with harmony. The Kipat tenure in the literature of land reform is free from any disputes.

\section{POLITICAL CONSEQUENCES}

The political power was not centered on some handful persons due to the Kipat system. Kipat was not like Jamindari system and there was no masterservant relationship between peasants and Jimmawals. Generally, the decision was made in Kipatia society by social consensus but not by any order of Jimmawal. Decisions were made by him only. Political settings and power controlling did not so much change due to the abolition of Kipat tenure. The situation that existed before the abolition continued after the abolition in some cases. The cause of minimal change is due to the recording of the land. The record of land was with Jimmawals and it was based on very old technique and cadastral survey. In eastern hill the cadastral survey of 1950 BS was said to be complete. The new cadastral survey of land in ex-Kipat area was finished in 2052 $\mathrm{BS}$, the last year of the survey campaign made after the land reform was declared in 2021 BS. Before new cadastral survey, land records were in the control of the Jimmawals and the Jimmawals also ran minor administration including the fixation of boundaries in the minor dispute. They could rearrange land by the Pajani. So, political power was redirected from the Jimmawals.

\section{ECONOMIC CONSEQUENCES}

The holding pattern was not in big scale in Kipat tenure. So there was less room for the distributional effect. The data were not proper so how much land changed into Raikar after the abolition of Kipat is some how unknown. The researcher tried to write a case study report in the effect of Kipat abolition, but 
there was a compulsion to divert the focus area due to the lack, inadequacy and unreliability of data. It has already been said that the cadastral survey was very old. The last survey was said to be conducted in 2050 BS. In 1995 BS resurveying was cancelled due to corruption. After 1950 BS, situation had changed until the date of Kipat abolition. New tillage system change of boundaries and partition and new system of holding, selling, purchasing and mortgaging of Kipat land came into use.

The overall effect was not substantially shown due to the abolition of Kipat tenure. So, it can be said that due to the abolition of Kipat tenure administrative reform was made but not economic reform.

After the abolition of Kipat, land was not distributed or consolidated. Holding pattern was not changed as non-Kipatiyas also had the permanent ownership of Kipat land. The Kipat was nearly equal to the selling price of land, and if land prices rose, addendum was given to Kipatias. So before the abolition, if Kipatias wanted to give up the control of their land, they could shift the control of Kipat land to non-Kipatiyas by either one or other methods; though permanent ownership was not transferred.

This uniqueness of transforming land control had established a peculiar relationship with land seller buyer in eastern hill. This relationship still exists in this locality. The relation of seller and buyer is very smooth in this region. This is a social consequence of Kipat land tenure system.

Today, the revenue from land is insignificant in total revenue due to different causes. In Rana regime it was the main part of the revenue. But after the planned development has initiated the portion of land tax, the revenue is gradually decreasing. Dr. Badri Pokhrel (1991) also accepts this phenomenon. The land administration and data were under the control of Jimmawals, Patwari and Jimindars. Revenue was collected in cash and kind. The rate was not high as the government didn't impose burden on peasants. The revenue administration was not prompt and fast and it was very lengthy chain. So, the revenue increase due to the abolition of Kipat land was minimal in total revenue of government. Kipat land was not so highly productive land. Mostly, Kipat was in hilly region and quality of the land was not so good. By this, it can be projected that extra revenue from Kipat abolition is not significant.

\section{WORKS CITED}

Herrerra, R.T. 1997. Land Reform, 1997/1. FAO Bulletin. Recent FAO experiences in Land Reform and Land Tenure, Rome. Pages 53.

Pokhrel, B. 1991. Land Revenue Administration in Nepal. Commonwealth Publishers, Delhi.

Regmi, M.C. 1977. Land Ownership in Nepal. Adroit Publication, Delhi.

Sherpa, S.S. 2002. Sherpas' are the Forefather of South Asian (East Asian) Indigenous Tribe. Sherpa Reflection. 7(1), Kathmandu.

Shrestha, S.K. 1985. Historical Study of Limbuyan (A Research). MS. Ganga Devi Shrestha, Dhankuta. 